\title{
Effect of pMDI isocyanate additive on mechanical and thermal properties of Kenaf fibre reinforced thermoplastic polyurethane composites
}

\author{
Y A EL-SHEKEIL* ${ }^{*}, S$ M SAPUAN, K ABDAN ${ }^{\dagger}$, E S ZAINUDIN ${ }^{\ddagger}$ and O M AL-SHUJA'A ${ }^{\#}$ \\ Department of Mechanical and Manufacturing Engineering, ${ }^{\dagger}$ Department of Biological and Agricultural Engineering, \\ Faculty of Engineering, Universiti Putra Malaysia, 43400 UPM, Serdang, Selangor, Malaysia \\ \$aboratory of Bio-Composite Technology, Institute of Tropical Forestry and Forest Products, Universiti Putra Malaysia, \\ 43400 UPM, Serdang, Selangor, Malaysia \\ \#Department of Chemistry, Faculty of Applied Science, Thamar University, Thamar, Yemen
}

MS received 8 December 2011; revised 30 January 2012

\begin{abstract}
The effect of polymeric methylene diphenyl diisocyanate (pMDI) on mechanical and thermal properties of Kenaf fibre (KF) reinforced thermoplastic polyurethane (TPU) composites was studied. Various percentages viz. $2 \%, 4 \%$ and $6 \%$, were studied. The composites were characterized by using tensile testing, thermogravimetric analysis (TG), differential scanning calorimetry (DSC) and fourier transform infrared spectroscopy (FTIR). It was noticed that the addition of pMDI $2 \%, 4 \%$ and $6 \%$ did not induce a better tensile nor thermal properties.
\end{abstract}

Keywords. Natural fibre composites; thermoplastic polyurethane; Kenaf fibres; pMDI additive; thermal properties; FTIR.

\section{Introduction}

Composite materials consist of two or more materials mixed together to form a new material with unique properties. These properties differ from the properties of the separate components. Properties of the new material are mainly affected by the interfacial bonding between fibres and matrix. Incompatibility of natural fibres and polymers is one of the main barriers facing this industry. Researchers have tried to overcome this problem by many ways such as pre-treating fibres, using additives, coupling agents and binders.

Various fibre pre-treatments and coupling agents have been used to enhance the fibre matrix interface. Physical and chemical methods of surface treatments of natural fibres have been reviewed by Bledzki and co-workers (1996). John and Anandjiwala (2008) reviewed the mechanisms of chemical modifications of natural fibres reinforced composites i.e. alkali, acetylation and silane treatments (John and Anandjiwala 2008). Kalia and co-workers have reviewed the use of pre-treated natural fibres in polymer matrix-based composites and the effect of surface modification on the properties of fibres and composites (Kalia et al 2009).

Natural fibre reinforced polymers have a growing demand due to benefits such as less abrasiveness to equipment, renewability, biodegradability and reduction in weight and cost. Hydrophilic nature of natural fibres vs hydrophobic nature of most polymers used in this field is amongst the difficulties that limit the utilization of natural fibre composites. This difference causes lack of adhesion and wettability.

\footnotetext{
*Author for correspondence (y_shekeil@yahoo.com)
}

The advantage of polyurethane used in this research is that polyurethane is hydrophilic (i.e. it is polar in nature).

The active isocyanate group can react with most materials that have active hydrogen groups. In natural fibres cellulose has active hydroxyl groups that may react with the NCO active group of the isocyanate (Kalia et al 2009). Isocyanate has been used as a coupling agent and an additive (i.e. to be charged into the mixer while mixing fibres and matrix) (Wirawan et al 2011). The other method is to chemical pre-treatment of natural fibres using isocyanate treatment (George et al 1997).

Kenaf plant is an annual plant that can be harvested 2-3 times a year. It can grow up to 3-4 m within 4-5 months.

Kenaf plant has two layers; bast and core. Kenaf bast represents one third of the plant. Core represents the rest. Kenaf bast fibre has superior mechanical properties than the other parts of the plant (Aji et al 2009). This paper studies effect of $2 \%, 4 \%$ and $6 \%$ pMDI as an additive on TPU/KF $30 \%$ by weight. Tensile properties were tested. TG was carried out. FTIR was conducted, to further investigate in depth, the effect of pMDI on TPU/KF composite.

\section{Materials}

Polyester based thermoplastic polyurethane (TPU) and polymeric methylene diphenyl diisocyanate (pMDI) were obtained from Bayer Co., Malaysia. Properties of TPU used in the study are as follows: specific gravity: 1.21 ; tensile strength: $48 \mathrm{MPa}$; melting temperature: $210^{\circ} \mathrm{C}$ and hardness: 55 shore $\mathrm{D}$. 
Kenaf bast fibre (KenafV36) was supplied from KEFI, Malaysia.

\section{Methods}

\subsection{Fibre preparation}

Kenaf bast fibre was extracted by mechanical decortication. Fibre was pulverized using Fritsch Pulverisette mill. Pulverized fibre was sieved using an auto shaker sieve into size $(125-300 \mu \mathrm{m})$ using a mesh size of 50-120. Moisture content of fibres was in the range $8 \cdot 3-9 \cdot 6 \%$.

\subsection{Composite preparation}

TPU/KF composite was mixed using Haake Polydrive R600 internal mixer. Matrix was charged into the mixer until torque was stabilized, then fibre was added into the mixer. A 30\% fibre loading was fixed throughout the study. pMDI was charged into the mixer around $2 \mathrm{~min}$ after addition of matrix.

The compression machine used in pressing the samples is Vechno Vation 40 ton Compression Moulding. The samples were pre-heated for $7 \mathrm{~min}$ at $190^{\circ} \mathrm{C}$. Then they were hot pressed for $10 \mathrm{~min}$ at $190^{\circ} \mathrm{C}$ and the sheets were placed between two plates of a cold press to cool at $25^{\circ} \mathrm{C}$ for $5 \mathrm{~min}$.

\subsection{Mechanical characterization}

Tensile properties were measured using Instron 3365 machine, according to ASTM D 638. The specimens were cut into dumbbell shapes using a hydraulic cutter machine. Five specimens were tested with a crosshead speed of $5 \mathrm{~mm} / \mathrm{min}$.

\subsection{FTIR spectroscopy characterization}

Perkin Elmer Spectrum 100 FT-IR Spectrometer was used to record FTIR spectra of untreated and treated composites.

\subsection{Thermogravimetric analysis}

Mettler Toledo TGA/SDTA851 ${ }^{\mathrm{e}}$ analyser was used to perform TG tests. The tests were carried out in the temperature range between room temperature and $600^{\circ} \mathrm{C}$ at a heating rate of $10^{\circ} \mathrm{C} / \mathrm{min}$ in an atmosphere of nitrogen flowing at $10 \mathrm{ml} / \mathrm{min}$. A sample of $5-20 \mathrm{mg}$ of the materials was heated in a sample pan.

\subsection{Differential scanning calorimetry}

Mettler Toledo DSC823 ${ }^{\mathrm{e}}$ analyser was used to perform DSC thermal analyses. The tests were carried out in the temperature range between room temperature and $300^{\circ} \mathrm{C}$ at a heating rate of $10^{\circ} \mathrm{C} / \mathrm{min}$ in nitrogen atmosphere flowing at $10 \mathrm{ml} / \mathrm{min}$. Approximately $5 \mathrm{mg}$ of the materials were heated in the sample pan. An empty pan was used as the reference.

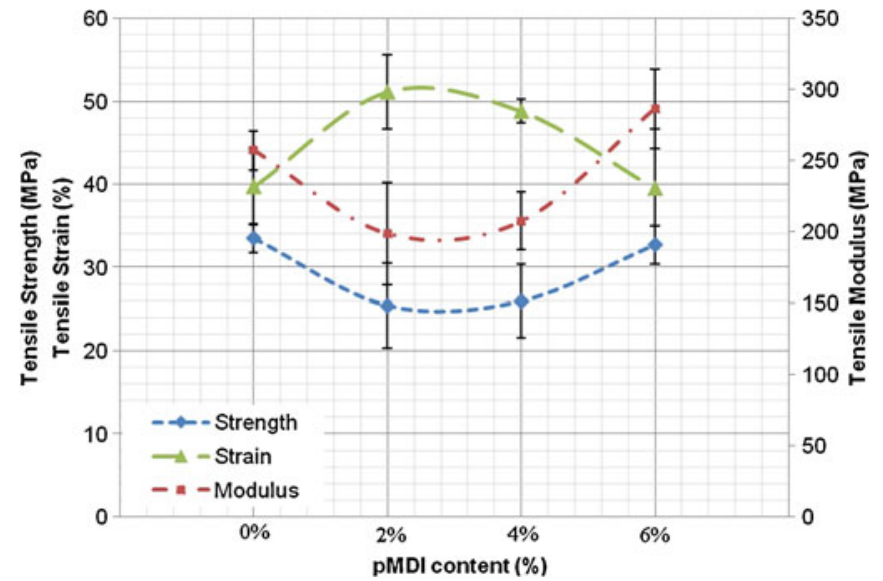

Figure 1. Effect of pMDI on tensile properties of TPU/KF.

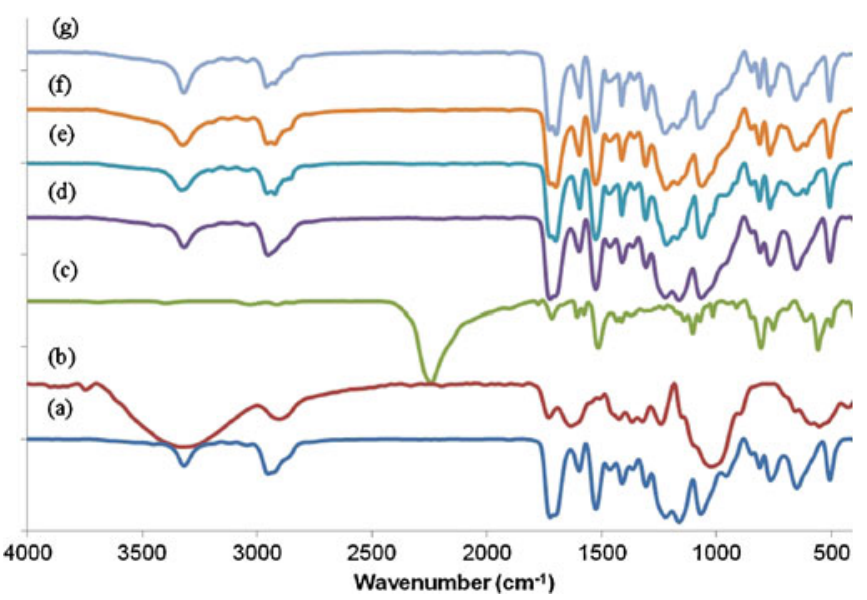

Figure 2. FTIR for (a) pure TPU, (b) Kenaf fibre, (c) pMDI, (d) TPU/KF untreated, (e) TPU/KF treated with $2 \% \mathrm{pMDI}$, (f) TPU/KF treated with $4 \% \mathrm{pMDI}$ and $(\mathrm{g}) \mathrm{TPU} / \mathrm{KF}$ treated with $6 \% \mathrm{pMDI}$.

\section{Results and discussion}

\subsection{Effect of pMDI additive on tensile properties of $T P U / K F$}

Figure 1 shows effect of pMDI additive on the tensile properties of TPU/KF composite. Untreated composite has shown the best tensile strength of $33 \mathrm{MPa}$. The addition of $2 \%$ and $4 \%$ of pMDI decreased the tensile strength and modulus significantly by $24 \%$ and $22 \%$, respectively. Simultaneously, $2 \%$ and $4 \%$ additive of pMDI increased the strain by $29 \%$ and $23 \%$, respectively. The addition of $6 \%$ pMDI slightly reduced tensile strength (i.e. $\sim 1 \%$ ), however, tensile modulus increased from 257 to $286 \mathrm{MPa}$ (i.e. $\sim 11 \%$ increment). At the pMDI content of $6 \%$ the strain was maintained at the same value approximately.

\subsection{FTIR spectroscopy}

Figure 2 shows FTIR spectra of (a) TPU, (b) KF, (c) pMDI, (d) TPU/KF untreated, (e) TPU/KF with $2 \% \mathrm{pMDI}$ additive, 
Table 1. Main FTIR bands of TPU, KF, pMDI, TPU/KF untreated, TPU/KF treated $2 \%$ pMDI, TPU/KF treated $4 \%$ pMDI and TPU/KF treated $6 \%$ pMDI.

\begin{tabular}{|c|c|c|c|c|c|c|c|c|c|}
\hline $\begin{array}{l}\text { Peak location }\left(\mathrm{cm}^{-1}\right) \\
\text { (Hatchett } \text { et al } 2005 \text {; } \\
\text { Jena } \text { et al } 2007 ; \\
\text { Bakare } \text { et al } 2010)\end{array}$ & $\begin{array}{l}\text { Chemical } \\
\text { structure }\end{array}$ & Motion & TPU & KF & pMDI & TPU/KF & $\begin{array}{c}\text { TPU/KF } 2 \% \\
\text { pMDI }\end{array}$ & $\begin{array}{c}\text { TPU/KF } 4 \% \\
\text { pMDI }\end{array}$ & $\begin{array}{l}\text { TPU/KF 6\% } \\
\text { pMDI }\end{array}$ \\
\hline $3200-3500$ & $\mathrm{O}-\mathrm{H}$ & Hydrogen bonding & - & 3215 & - & - & - & - & - \\
\hline $3200-3400$ & $\mathrm{~N}-\mathrm{H}$ & Stretching & 3315 & - & - & 3324 & 3324 & 3324 & 3324 \\
\hline $3000-2800$ & $\mathrm{CH}_{2}$ and $\mathrm{CH}_{3}$ & Stretching & 2985,2936 & 2900 & & $2870-2950$ & $\begin{array}{l}2850,2870 \\
2930,2960\end{array}$ & $\begin{array}{l}2850,2870 \\
2930,2960\end{array}$ & $\begin{array}{l}2850,2870, \\
2930,2960\end{array}$ \\
\hline $2300-2000$ & $\mathrm{~N}=\mathrm{C}=\mathrm{O}$ & Isocyanate stretching & - & - & 2240 & - & - & - & - \\
\hline 1740 & $\mathrm{C}=\mathrm{O}$ & $\begin{array}{c}\text { Non-bonded urethane } \\
\text { stretching }\end{array}$ & 1729 & - & - & 1729 & 1729 & 1729 & 1729 \\
\hline 1690 & $\mathrm{C}=\mathrm{O}$ & Associated urethane & 1700 & - & - & 1700 & 1700 & 1700 & 1700 \\
\hline $1590-1650$ & $\mathrm{~N}-\mathrm{H}$ & Bending & 1603 & - & - & 1603 & 1603 & 1603 & 1603 \\
\hline $1550-1510$ & $\mathrm{H}-\mathrm{N}-\mathrm{C}=\mathrm{O}$ Amide II & Combined motion & 1530 & - & - & 1531 & 1531 & 1531 & 1531 \\
\hline $1000-1300$ & $\mathrm{C}-\mathrm{O}$ & Stretching & 1161,1223 & - & - & 1161,1223 & 1169,1219 & 1169,1219 & 1169,1223 \\
\hline
\end{tabular}

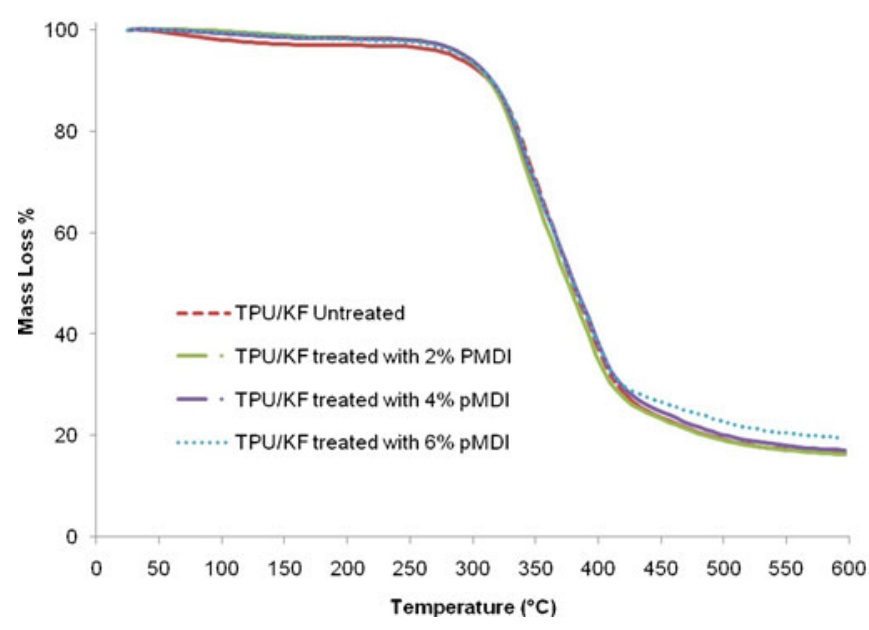

Figure 3. TG thermogram of TPU/KF untreated, TPU/KF treated with $2 \%$ pMDI, TPU/KF treated with $4 \%$ pMDI and TPU/KF treated with $6 \%$ pMDI composites.

(f) $\mathrm{TPU} / \mathrm{KF}$ with $4 \%$ pMDI additive and (g) TPU/KF with $6 \%$ pMDI additive. The main IR bands are summarized in table 1.

Carbonyl absorption of TPU displayed two bands at 1729 and $1700 \mathrm{~cm}^{-1}$. The network structure formed between TPU/KF untreated and treated with 2,4 and $6 \%$ pMDI is confirmed by the difference in the intensity of absorption (Senich and MacKnight 1980; Ahmad et al 2011); exactly, it is observed by an increase of intensity of $\mathrm{C}=\mathrm{O}$ and $\mathrm{C}-\mathrm{O}$ absorptions at 1700 and $1223 \mathrm{~cm}^{-1}$, respectively, by increasing the percentage of pDMI. Also, it is confirmed by complete disappearance of isosyanate peak of $(\mathrm{N}=\mathrm{C}=\mathrm{O})$ at $2240 \mathrm{~cm}^{-1}$.

\subsection{Thermogravimetric analysis}

Figures 3 and 4 illustrate TG and DTG of TPU/KF untreated, TPU/KF treated with $2 \%$ pMDI, TPU/KF treated with $4 \%$

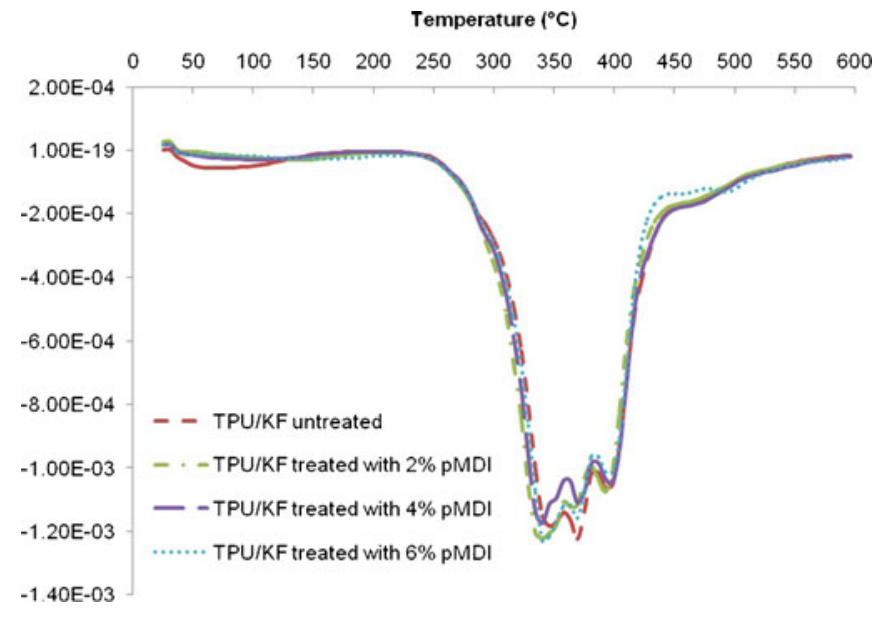

Figure 4. DTG of TPU/KF untreated, TPU/KF treated with $2 \%$ pMDI, TPU/KF treated with $4 \% \mathrm{pMDI}$ and TPU/KF treated with $6 \%$ pMDI composites.

pMDI and TPU/KF treated with $6 \%$ pMDI composites. Weight loss of the composites is presented in table 2. The weight loss of untreated composite between 25 and $100^{\circ} \mathrm{C}$ was more than that of all the treated composites. This indicates availability of more moisture in the untreated than in treated composites (El-Shekeil and Omar 2007).

The $2 \%$ pMDI additive resulted in slight increase of weight loss between 250 and $400^{\circ} \mathrm{C}$. This means that this formulation is less stable than the other formulations. Addition of $6 \%$ pMDI resulted in less weight less than the addition of $2 \%$ pMDI and $4 \%$ pMDI, in the temperature range between 420 and $600^{\circ} \mathrm{C}$. This indicates that the addition of $6 \%$ pMDI resulted in a more stable composite than $2 \%$ pMDI and $4 \%$ pMDI.

It can be noted from TG (figure 3) that the decomposition of all the composites occurs in one step between 250 and $450^{\circ} \mathrm{C}$. However, figure 4 clarifies that a complicated decomposition occurs in three steps. Table 3 summarizes 
Table 2. Weight loss percentage of TPU/KF untreated, TPU/KF treated $2 \% \mathrm{pMDI}$, TPU/KF treated $4 \%$ pMDI and TPU/KF treated $6 \%$ pMDI composites.

\begin{tabular}{|c|c|c|c|c|c|c|c|}
\hline \multirow[b]{2}{*}{ Material } & \multicolumn{7}{|c|}{ Weight loss (\%) } \\
\hline & $T_{100 \cdot 83^{\circ} \mathrm{C}}$ & $T_{252.5^{\circ} \mathrm{C}}$ & $T_{299 \cdot 16^{\circ} \mathrm{C}}$ & $T_{351.66^{\circ} \mathrm{C}}$ & $T_{398.33^{\circ} \mathrm{C}}$ & $T_{450 \cdot 83^{\circ} \mathrm{C}}$ & $T_{503.33^{\circ} \mathrm{C}}$ \\
\hline TPU/KF untreated & 1.91 & $3 \cdot 35$ & $7 \cdot 1$ & $30 \cdot 59$ & 61.63 & $76 \cdot 49$ & $81 \cdot 02$ \\
\hline TPU/KF treated with $2 \%$ pMDI & $0 \cdot 23$ & 1.93 & $6 \cdot 18$ & 33.95 & 63.98 & $76 \cdot 79$ & $81 \cdot 15$ \\
\hline TPU/KF treated with $4 \%$ pMDI & $0 \cdot 71$ & $2 \cdot 03$ & $5 \cdot 98$ & 31.41 & $60 \cdot 59$ & $75 \cdot 33$ & $80 \cdot 09$ \\
\hline TPU/KF treated with $6 \%$ pMDI & 0.43 & 2.43 & $6 \cdot 33$ & $31 \cdot 15$ & $60 \cdot 9$ & $73 \cdot 43$ & 77.49 \\
\hline
\end{tabular}

Table 3. Maximum temperature of decomposition steps $\left(T_{\max }\right)$ from DTG in the range between 250 and $450^{\circ} \mathrm{C}$ of untreated and treated composites.

\begin{tabular}{|c|c|c|c|c|}
\hline \multirow[b]{2}{*}{ Step no. } & \multicolumn{4}{|c|}{$T_{\max }\left({ }^{\circ} \mathrm{C}\right)$} \\
\hline & $\begin{array}{l}\text { TPU/KF } \\
\text { untreated }\end{array}$ & $\begin{array}{l}\text { TPU/KF treated } \\
\text { with } 2 \% \text { pMDI }\end{array}$ & $\begin{array}{l}\text { TPU/KF treated } \\
\text { with } 4 \% \text { pMDI }\end{array}$ & $\begin{array}{l}\text { TPU/KF treated } \\
\text { with } 6 \% \text { pMDI }\end{array}$ \\
\hline 1. & 347 & 339 & 340 & 342 \\
\hline 2. & 369 & 365 & 370 & 370 \\
\hline 3. & 396 & 392 & 397 & 397 \\
\hline
\end{tabular}

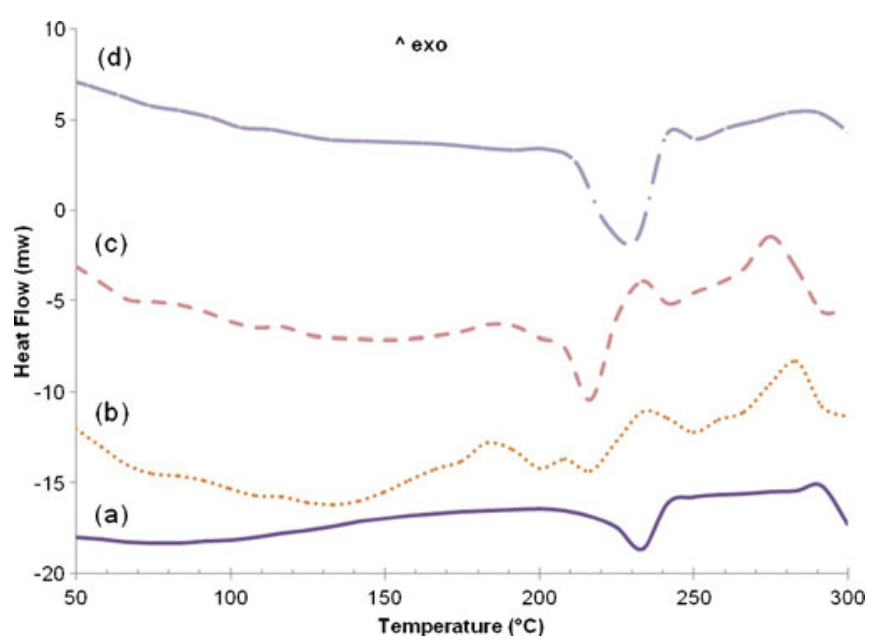

Figure 5. DSC thermogram of (a) untreated TPU/KF, (b) TPU/KF treated with $2 \% \mathrm{pMDI}$, (c) TPU/KF treated with $4 \%$ pMDI and (d) TPU/KF treated with $6 \%$ pMDI.

the highest decomposition temperatures $\left(T_{\max }\right)$ for the three steps of decomposition between 250 and $450^{\circ}$ from DTG. In table 3 , it can be noted that untreated composite has the highest decomposition temperature of the three steps compared to treated composites.

From table 3 addition of $2 \%$ pMDI resulted in the lowest decomposition temperatures of the three steps. After that, $T_{\max }$ increased by raising the percentage of pMDI. This sequence of $T_{\max }$ is clear in the first step which is 347,339 , 340 and $342^{\circ} \mathrm{C}$, for TPU/KF untreated, TPU/KF treated with $2 \% \mathrm{pMDI}, \mathrm{TPU} / \mathrm{KF}$ treated with $4 \% \mathrm{pMDI}$ and TPU/KF treated with $6 \%$ pMDI, respectively. Therefore, addition of $6 \%$ pMDI is judged to be more stable than the addition of $2 \%$ and $4 \%$.

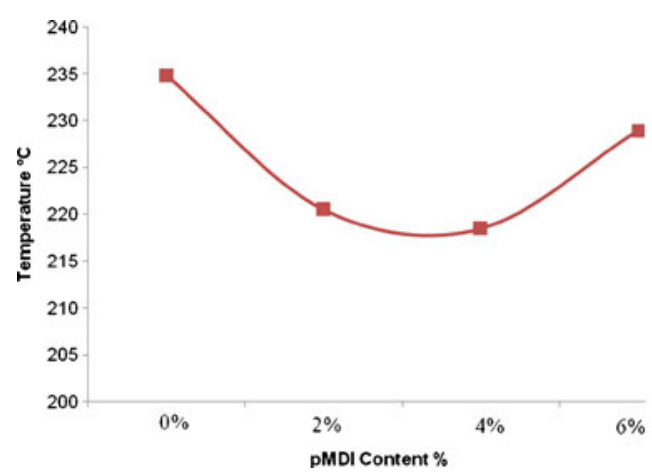

Figure 6. Variation of melting point temperature $\left(T_{\mathrm{m}}\right)$ vs pMDI content to TPU/KF composite.

\subsection{Differential scanning calorimetry}

Figure 5 shows DSC of TPU/KF untreated, TPU/KF treated with $2 \%$ pMDI, TPU/KF treated with $4 \%$ pMDI and TPU/KF treated with $6 \%$ pMDI composites. Peak melting temperature $\left(T_{\mathrm{m}}\right)$ of untreated and treated composites were observed in figure 6 . It is noted from figure 6 that melting temperature, $T_{\mathrm{m}}$, was effected by the addition of pMDI. $T_{\mathrm{m}}$ was $234^{\circ} \mathrm{C}$ for the untreated composite. $T_{\mathrm{m}}$ decreased to $220^{\circ} \mathrm{C}$ and $218^{\circ} \mathrm{C}$ with the addition of pMDI $2 \%$ and $4 \%$, respectively. $T_{\mathrm{m}}$ increased with the addition of $6 \%$ pMDI to reach $228^{\circ} \mathrm{C}$. This change in melting temperature indicates the change in mobility of molecules; i.e., change in the fibre-matrix interaction. Thus, different percentages of pMDI additive effect, by shifting of $T_{\mathrm{m}}$, may be attributed to the availability of stacking or intermolecular bonding in composites. $T_{\mathrm{m}}$ of TPU/KF treated with $6 \%$ pMDI additive comes the closest degree for TPU/KF untreated, then, the TPU/KF treated with $2 \%$ pMDI and TPU/KF treated with $4 \%$ pMDI. 


\section{Conclusions}

The following points can be concluded from this work:

(I) Addition of 2\%, 4\% and 6\% of pMDI reduced the stacking between the matrix and fibres. This is clear from the tensile strength, whereas all the percentages have less tensile strength than untreated composite.

(II) The $6 \%$ pMDI additive showed a better strength than $2 \%$ and $4 \%$. This trend is consistent with thermal properties; while in TG 6\% pMDI additive showed a better stability than $2 \%$ and $4 \%$. Furthermore, melting temperature shown in DSC thermogram showed the same trend.

(III) It can be concluded that pMDI additive with 2\%, $4 \%$ and $6 \%$ has neither enhanced the mechanical nor the thermal properties of TPU/KF composite.

\section{Acknowledgements}

Fundamental Research Grant Scheme (FRGS), Ministry of Higher Education Malaysia, grant number (01-10-10924FR) is acknowledged for support. The authors wish to thank Bayer Co., Malaysia, for TPU and pMDI supply and information provided.

\section{References}

Ahmad S H, Rasid R, Bonnia N N, Zainol I, Mamun A A, Bledzki A K and Beg M D H 2011 J. Compos. Mater. 45203

Aji I S, Sapuan S M, Zainudin E S and Abdan K 2009 Int. J. Mech. Mater. Eng. 4239

Bakare I O, Okieimen F E, Pavithran C, Abdul Khalil H P S and Brahmakumar M 2010 Mater. Des. 314274

Bledzki A K, Reihmane S and Gassan J 1996 J. Appl. Polym. Sci. 591329

El-Shekeil A G and Omar M 2007 J. Macromol. Sci. Part A: Pure Appl. Chem. 44931

George J, Bhagawan S S and Thomas S 1997 Compos. Sci. Technol. $\mathbf{5 8} 1471$

Hatchett D W, Kodippili G, Kinyanjui J M, Benincasa F and Sapochak L 2005 Polym. Degrad. Stab. 87555

Jena K K, Chattopadhyay D K and Raju K 2007 Eur. Polym. J. 43 1825

John M J and Anandjiwala R D 2008 Polym. Compos. 29187

Kalia S, Kaith B S and Kaur I 2009 Polym. Eng. Sci. 491253

Senich G A and MacKnight W J 1980 Macromolecules 13106

Wirawan R, Sapuan S M, Yunus R and Abdan K 2011 J. Compos. Mater. 451667 (DOI: 10.1177/0021998310385030) 